\title{
Yield and Fruit Quality Response of Drip-Irrigated Melon to the Duration of Irrigation Season
}

\author{
Neslihan ȘENGÜL ${ }^{*} \quad$ Osman YILDIRIM² Nilgün HALLORAN ${ }^{3}$ Șeyda ÇAVUȘOĞLU4 \\ Evran DOĞAN 5
}

\author{
'Central Research Institute For Field Crops, Ankara- Turkey \\ 2Univ. of Ankara, Faculty of Agriculture, Dept. of Farm Structures and Irrigation, Ankara-Turkey \\ ${ }^{3}$ Univ. of Ankara, Faculty of Agriculture, Dept. of Horticulture, Ankara, Turkey \\ ${ }^{4}$ Univ. of Yuzuncu Yıl, Faculty of Agriculture, Dept. of Horticulture, Van, Turkey \\ ${ }^{5}$ Department of Training Extension and Publications, Ankara, Turkey
}

\author{
*Corresponding author e-mail (Sorumlu yazar): nsengul@gmail.com \\ Received date (Geliș tarihi): 28.05.2014 \\ Accepted date (Kabul tarihi): 11.08.2014
}

\begin{abstract}
A field study was conducted in Ankara, a semi-arid region of Central Anatolia, Turkey. Yuva and Cantaloupe Sally $F_{1}$ melon cultivars (Cucumis melo L.) were irrigated by drip method from transplanting to the beginning of the flowering $\left(I_{f}\right)$, fruit set $\left(l_{f s}\right)$, ripening $\left(I_{r}\right)$, and harvest $\left(I_{h}\right)$, and included a non-irrigated treatment $\left(\mathrm{I}_{0}\right)$. Growth, yield, and fruit quality parameters in response to the duration of irrigation season were determined. The number of shoots and female flowers per plant, shoot length, and titratable acidity in Cantaloupe were lower than in Yuva, while similar total soluble solids content of fruit flesh was obtained in both cultivars. Irrigation application provided for an increase in the fruit number per plant, fruit size, fruit weight, and yield, and resulted in a decrease in total soluble solids and the ratings of sensory characteristics compared with non irrigated treatments in both cultivars, but these increases and decreases in the above parameters could not be correlated with the increase in the duration of the irrigation season, hence the amount of seasonal irrigation water. The highest yields were obtained in $\mathrm{I}_{\mathrm{r}}$ treatment in Yuva and in $\mathrm{I}_{\mathrm{r}}$ and $\mathrm{I}_{\mathrm{h}}$ treatments in Cantaloupe. Continuing irrigation during fruit ripening furthered shoot growth in both cultivars, did not affect yield in Cantaloupe, and remarkably reduced yield in Yuva. Irrigation from the stage of transplanting until the beginning of fruit ripening was suggested as well for both cultivars with regard to considerably high yield and high fruit quality. In this irrigation program, irrigation water amounts of $388.3-441.4 \mathrm{~mm}$ were applied, seasonal evapotranspiration of 499.0-587.1 mm was found, and a yield per plant of 6105-6206 $\mathrm{g}$ in Yuva and 7533-7878 $\mathrm{g}$ in Cantaloupe was obtained.
\end{abstract}

Key Words: Cantaloupe, drip irrigation, fruit quality, yield, Yuva

\section{Büyüme Mevsimi Boyunca Damla Yöntemiyle Sulanan Kavunun Verim ve Meyve Kalitesine Tepkisi}

\section{Öz}

Tarla denemeleri yarı-kurak Orta Anadolu koșullarında Ankara, Türkiye'de yürütülmüștür. Sulanmayan parsellerin $\left(I_{0}\right)$ yanı sıra Yuva ve Kantalop tipi Sally F1 çeșidi kavunlar (Cucumis melo L.), dikimden itibaren çiçeklenme bașlangıcına $\left(I_{f}\right)$, meyve olușumu bașlangıcına $\left(I_{\mathrm{fs}}\right)$, olgunlașma bașlangııına $\left(I_{\mathrm{r}}\right)$ ve hasata $\left(\mathrm{I}_{\mathrm{h}}\right)$ kadar damla sulama yöntemiyle sulanmıștır. Sulama sezonu boyunca, vejetatif ve generatif gelișme, verim ve meyve kalitesi parametreleri belirlenmiștir. Kantalop çeșidinde, bitki bașına diși çiçek ve sürgün sayısı, 
sürgün uzunluğu ve titrasyon asitliği değerleri Yuva çeșidinden daha düșük, suda çözünebilir toplam kuru madde miktarları ise her iki çeșitte benzer olmuștur. Sulama uygulamaları, bitki bașına meyve sayısı, meyve büyüklüğü, meyve ağırlığı ve verimi arttırmıș, sulanmayan uygulama ile kıyaslandığında kuru madde ve tat puanı değerlerini düșürmüștür. En yüksek verim Yuva çeșidinde olgunlașma bașlangıcına kadar sulama suyu uygulamasından, Kantalop çeșidinde ise olgunlașma bașlangıcı ve hasata kadar su uygulanan parsellerden elde edilmiștir.

Sulamaya olgunlașma periyodunda $\left(I_{r}\right)$ devam edilmesi her iki çeșitte sürgün büyümesini ilerletmiș, Kantalop çeșidinde verimi etkilememiș, Yuva çeșidinde ise verimi nispeten düșürmüștür. Yüksek verim ve kalite için her iki çeșitte de sulamanın olgunlașma bașlangıcına $\left(I_{r}\right)$ kadar sürdürülmesi tavsiye edilmektedir. Bu sulama programında, uygulanan sulama suyu miktarı 388.3-441.4 mm, mevsimlik bitki su tüketimi 499.0-587.1 mm ve bitki bașına meyve verimi Yuva çeșidinde 6105-6206 g, Kantalop çeșidinde ise 7533$7878 \mathrm{~g}$ olarak elde edilmiștir.

Anahtar Kelimeler: Kantalop, damla sulama, meyve kalitesi, verim, Yuva

\section{INTRODUCTION}

The aim in crop production produce high yield and quality products which reach consumers with least quality loss. This is closely related to ecological conditions that the product is exposed to as well as cultural practices during the cultivation. Water is involve in many events in plants. Thus, water has a significant impact on the plant and fruit formation and development. In case of inadequate or unbalanced water is reduced melon fruit quality and fruit can not widened enough (Karaçalı, 1993).

Melons can be cultivated in dry and irrigated conditions. In order to cultivate in dry conditions, rainfall should be relatively high in the spring and early summer period (Günay, 1992). The main objective of melon cultivation is not to obtain not only the highest fruit yield per unit area. The aim is achieved high yield that fruit size and weight have high market value, good quality and long life durability after harvest (Warriner and Henderson, 1989; Hartz, 1997; Sousa, 1999). Melon (Cucumis melo L.) is an annual fruit with hairy body and superior aroma. Since it has summer and winter varieties, it is consumed all around the year. Turkey with proper climate conditions has a significant role in melon production (Sakaldas et al, 2009). World melon production is 20 million tons and China meets 6.6 million tons (34.5\%) of this world production and Turkey has the second place inproduction with 1.8 million ton (9.4\%) (BATEM, 2010).

Melon is moderately sensitive to soil salinity and the lack of soil water (Kușvuran, 2007). The most sensitive periods for soil water deficit are fruit setting and flowering (Fabeiro et al., 2002). Soil water deficit occurring during the ripening stage does not significantly affect fruit yield and generally increases or does not change fruit quality, particularly soluble solids, which primarily represent the sugar content of fruit flesh (Warriner and Henderson, 1989; Shishido et al., 1992; Hartz, 1997; Gil et al., 2000; Faberio et al., 2002). Irrigation performed close to time of harvest causes a reduction in soluble solids (Bhella, 1985; Lester et al., 1994). Application of saline water lowers yield, but results in an increase in soluble solids in general (Medlinger and Fossen, 1993; Meiri et al., 1995; Amor et al., 1998).

Melon is commonly irrigated by furrow or drip methods. In soils with a considerably high water holding capacity and under full irrigation, similar yields could be obtained with both methods, but irrigation water requirements fall and water use efficiency rises with drip irrigation (Bogle and Hartz, 1986; Warriner and Henderson, 1989). Frequent irrigation causes cracks in fruit, and very rare irrigation limits root and shoot development and also fruit size and yield (Flocker et al., 1965; Pew and Gardner, 1983). Use of drip irrigation can increase fruit size and marketable yield and may also bring about early harvest in sandy soils (Shmueli and Goldberd, 1971; Bhella, 1985; Warriner and Henderson, 1989; Coelho et al., 1999; Sousa et al., 1999; Leskovar et al., 2001).

Irrigation at proper time with the proper amounts of water is a critical issue to provide optimum yield and quality in plant production (Tekiner et al., 2010). Yıldırım et al., (2009) obtained the highest yield from drip irrigation with full irrigation. Dogan et al., (2008) indicated melon 
yields of 25-30 Mg.ha-1 under irrigated conditions. Barros et al., (2002) applied different amounts of irrigation water $(233.8,222.4,204.4,183.5,158.9$ and $132.2 \mathrm{~mm})$ and nitrogenous fertilizer $(0,75$, 150 and $300 \mathrm{~kg} \mathrm{ha}^{-1}$ ) and received the highest yield with $222.4 \mathrm{~mm}$ irrigation water and $209.2 \mathrm{~kg} \mathrm{ha}^{-1}$ application (Sengul 2009). Cabello et al., (2009) studied the effects of different irrigations and nitrogen fertilization on melon yield and indicated that yield didn't decrease at 90\% irrigation with 90 $\mathrm{kg} \mathrm{ha}^{-1}$ nitrogen fertilization.

The studies related with the effect of irrigation programs on melon growth and yield indicate that selection of a particular cultivar could dictate the specific irrigation program and water requirements, in addition to the usual factors such as climate, soil, topography, and water resource. For this reason, this study was undertaken to determine appropriate irrigation program involved with irrigation season for drip-irrigated Yuva and Cantaloupe melons grown in soils with high water holding capacity in a semi-arid region.

\section{MATERIALS AND METHODS}

\section{Experimental site}

This study was carried out in an experimental field in the Horticultural Research Station of Agricultural Faculty of Ankara University, Turkey, $\left(40^{\circ} 01^{\prime} \mathrm{N}, 32^{\circ} 20^{\prime} \mathrm{E}, 825 \mathrm{~m}\right.$ above mean sea level) in the production periods of 2005 and 2006.

The station is situated in a semi-arid climatic region. Long term annual total precipitation is $396.2 \mathrm{~mm}$ and means temperature is $13.0^{\circ} \mathrm{C}$ $\left(100.0 \mathrm{~mm}\right.$ and $22.0^{\circ} \mathrm{C}$ for the production period of melon, among May and August). In the production periods of the experimental years, these values were $95.6 \mathrm{~mm}$ and $22.9^{\circ} \mathrm{C}$ in 2005 and $61.9 \mathrm{~mm}$ and $23.7^{\circ} \mathrm{C}$ in 2006.

In each experimental year, soil samples were collected at 0-30 cm, 30-60 cm, $60-90 \mathrm{~cm}$, and 90$120 \mathrm{~cm}$ soil layers of two profiles before starting of the experiments. Texture class, electrical conductivity, lime content, and available water-holding capacity were found clay-loam, 0.91-1.08 dS $\mathrm{m}^{-1}, 13.3-$ $15.5 \%$, and $151.4 \mathrm{~mm} \mathrm{~m}^{-1}$, respectively (Table 1).

Soils at the experimental site were deep and quite homogeneous in composition with respect to soil texture and topography. In addition, soil intake rate was found to be $5.4 \mathrm{~mm} \mathrm{~h}^{-1}$ using double ring inflitrometers. The water resource was a deep well, and the electrical conductivity of the irrigation water was found to be $1.9 \mathrm{dS} \mathrm{m}^{-1}$.

\section{Treatments and experimental design}

Yuva and Cantaloupe Sally F1 cultivars of melon (Cucumis melo L.) were irrigated by drip method. Treatments were full irrigation from transplanting to the beginning of flowering (onset of blooming, $I_{f}$ ), fruit set (setting of the first two fruits, $I_{f s}$ ), ripening (full fruit swelling, $I_{r}$ ), and harvest $\left(I_{h}\right)$ stages; a nonirrigated treatment $\left(\mathrm{I}_{0}\right)$ was also considered. Because soil texture and topography were quite homogeneous, the experimental design was a factorial randomized parcel design with 10-30 replications. Data obtained from an observed plant were taken as a replicate. Each parcel included four plant rows and 21 plants in each row. Plantation intervals were $1.40 \times 1.00 \mathrm{~m}$ (Gunay 1992; Sari et al., 2000). Observations and measurements were done on 10 plants for growth and on 30 plants for yield parameters in two rows in the middle of a parcel (Figure 1).

Table 1 . Some physical characteristics of soil in experimental site (average of two years)

Çizelge 1. Deneme alanı topraklarının bazı fiziksel özellikleri (iki yılın ortalaması)

\begin{tabular}{cccccccc}
\hline $\begin{array}{c}\text { Soil } \\
\text { depth } \\
(\mathrm{cm})\end{array}$ & $\begin{array}{c}\text { Texture } \\
\text { class }\end{array}$ & $\begin{array}{c}\text { Bulk } \\
\text { density, } \\
\gamma_{\mathrm{s}}\left(\mathrm{g} \mathrm{cm}^{-1}\right)\end{array}$ & $\begin{array}{c}\text { Field } \\
\text { capacity, } \\
\text { FC (\% vol.) }\end{array}$ & $\begin{array}{c}\text { Wilting } \\
\text { point, } \\
\text { WP (\% vol.) }\end{array}$ & $\begin{array}{c}\text { Electrical } \\
\text { conductivity, } \\
\left.\text { EC (dS m })^{-1}\right)\end{array}$ & $\begin{array}{c}\text { Lime } \\
\text { content } \\
(\%)\end{array}$ & $\begin{array}{c}\text { Available water } \\
\text { holding capacity } \\
(\mathrm{mm})\end{array}$ \\
\hline $0-30$ & $\mathrm{CL}$ & 1.08 & 43.7 & 29.0 & 0.91 & 13.3 & 44.1 \\
$30-60$ & $\mathrm{CL}$ & 1.23 & 46.2 & 31.7 & 1.08 & 13.2 & 43.5 \\
$60-90$ & $\mathrm{CL}$ & 1.27 & 47.7 & 30.7 & 0.95 & 14.0 & 51.0 \\
$90-120$ & $\mathrm{CL}$ & 1.20 & 43.0 & 30.2 & 1.08 & 15.5 & 38.4 \\
\hline $0-90$ & $\mathrm{Cl}$ & 1.19 & 45.9 & 30.5 & 0.98 & 13.5 & 138.6 \\
\hline $0-100$ & & & & & & 151.4 \\
\hline
\end{tabular}




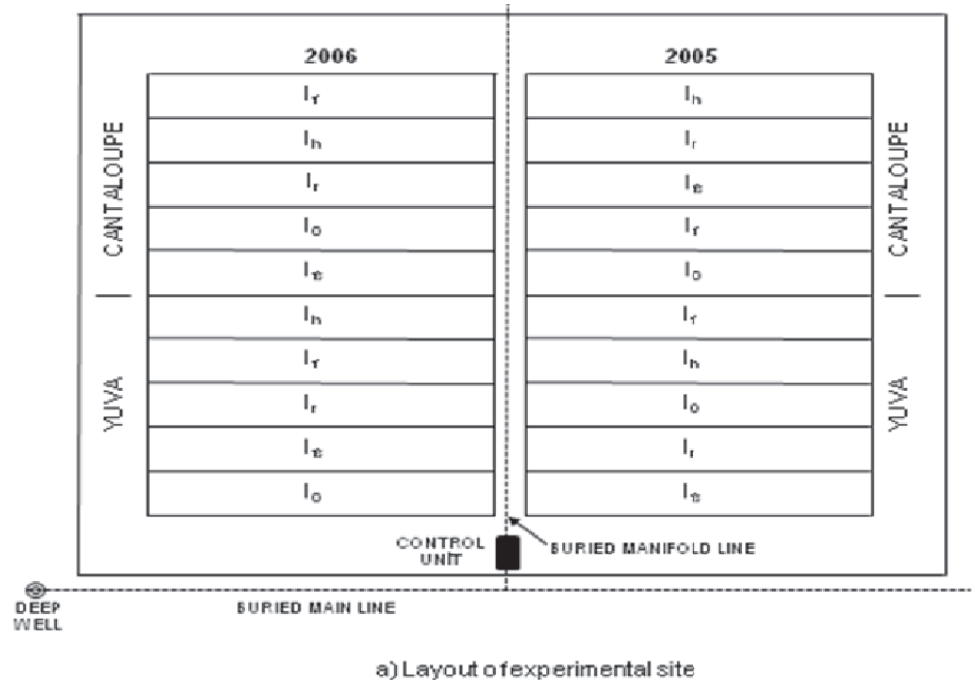

Figure 1. Experimental design

Șekil 1. Deneme deseni

The $\varnothing 16$ PE lateral drip lines were set about 25 $\mathrm{cm}$ close to each plant row. Drip lines consisted of in-line drippers with $4 \mathrm{~L} \mathrm{~h}^{-1}$ discharge rate at 1 bar operational pressure and drippers were spaced at $0.75 \mathrm{~m}$ in order to obtain a continuous wet strip along plant row and an appropriate wetted soil surface. This arrangement was chosen because of principles put forward by Papazafiriou (1980) and Yıldırım (2005) with respect to soil characteristics and row spacing of plants. In the first year, the percentage of wetted area was determined by digging soil with a shovel and measuring the shape of wetted soil surface at a soil depth of $20-30 \mathrm{~cm}$ at 18 locations one day after the first and second irrigations (Merriam and Keller, 1978). The mean percentage of the wetted area was determined $64.3 \%$

Melon seedlings were grown in the greenhouse and transplanted to the experimental plots in May (May 24 2005 and May 17 th 2006). Irrigation water was applied to all treatments during transplantation in order to bring existing soil moisture to the field capacity in a $90 \mathrm{~cm}$ soil depth (15.4 $\mathrm{mm}$ in 2005 and $34.7 \mathrm{~mm}$ in 2006).

\section{Soil moisture measurements}

The volumetric soil moisture content was measured in each $30 \mathrm{~cm}$ layer of the $120 \mathrm{~cm}$ soil depth using a neutron-probe (CPN, 503 DR Hydroprobe) calibrated for the soil characteristics of the experimental site. For this purpose, 2" aluminum access tubes were installed approximately in the middle of each parcel about $25 \mathrm{~cm}$ in proximity to a randomly chosen dripper.
The moisture contents at soil depths of $90 \mathrm{~cm}$ and $120 \mathrm{~cm}$ were used for the determination of water content applied for each irrigation and seasonal evapotranspiration, respectively.

\section{Irrigation}

The same irrigation water amount was applied to the irrigated treatments for both cultivars. Irrigation was initiated when $30-40 \%$ of water holding capacity was consumed (Faberio et al., 2002) in a $90 \mathrm{~cm}$ soil depth to bring the measured soil moisture content to field capacity. Water amount applied during each irrigation was calculated using the equation 1.

$d=\left[\left(F C O_{-30}-M_{-30}\right)+\left(F C_{30-60}-M_{30-60}\right)+\left(F C_{60-90}-M_{60-90}\right)\right](D)(P) / 100$

where $d$ is water amount applied during each irrigation (mm); $F_{0-30}, F_{30-60}, F_{60-90}$ is the field capacity (\% vol.) at the soil depth of $0-30 \mathrm{~cm}, 30-$ $60 \mathrm{~cm}, 60,90 \mathrm{~cm}$, respectively. $M_{0-30}, M_{30-60}, M_{60-90}$ is soil moisture (\% vol.) measured at the beginning of irrigation at soil depths indicated above, D is depth of soil layer $(300 \mathrm{~mm})$, and $P$ is the ratio of wetted soil area (0.643). Irrigation water amounts of between $26.3 \mathrm{~mm}$ and $35.0 \mathrm{~mm}$ were applied for each irrigation.

\section{Seasonal evapotranspiration}

Seasonal evapotranspiration was determined according to the soil moisture balance. For this purpose, the amount of seasonal irrigation water and the effective rainfall were added to the soil moisture difference measured at transplantation and at the last harvest (Jensen et al., 1989). 
Seasonal evapotranspiration was calculated using the equation 2 .

$$
E T=R+I-D \pm \Delta W
$$

where ET is seasonal evapotranspiration ( $\mathrm{mm})$, $R$ is effective rainfall $(\mathrm{mm}), \mathrm{I}$ is seasonal irrigation water applied $(\mathrm{mm}), \mathrm{D}$ is deep percolation $(\mathrm{mm})$, and $\Delta \mathrm{W}$ is seasonal variation in moisture content in $120 \mathrm{~cm}$ soil depth.

Soil moisture values measured at the $120 \mathrm{~cm}$ soil depth were considered for seasonal evapotranspiration to cover a probable deep percolation. Rainfall levels were considered to be effective because individual rainfall which occurred during production periods in experimental years was less than $25 \mathrm{~mm}$. In addition, surface runoff was not factored.

\section{Cultivation, plant protection, and fertilization}

Standard farming practices were used for cultivation and plant protection at the experimental site. Fertilizer type and amounts were determined based upon the results of soil productivity analysis, which were done for both experimental years. Drip fertilizer amounts of 340 $\mathrm{kg} \mathrm{ha}^{-1}$ 19-19-19, $80 \mathrm{~kg} \mathrm{ha}^{-1} 11-44-11,80 \mathrm{~kg} \mathrm{ha}^{-1}$, 16-6-31 in 2005 and $400 \mathrm{~kg} \mathrm{ha}^{-1}$ 19-19-19, 100 kg ha-1 11-44-11, $60 \mathrm{~kg} \mathrm{ha}^{-1}, 16-6-31$ in 2006 were applied by admixing with irrigation water and, being shared irrigations, applied during the relevant growth stages.

\section{Growth, yield, and fruit quality measurements}

The count of female flowers per plant was made during the flowering period on ten plants randomly chosen from 30 observed plants in each experimental plot. Shoot number per plant and shoot length were determined using the same 10 plants during a week stage before harvest. In each experimental plot, the number of marketable fruits per plant and the weight of each fruit were determined from 30 observed plants to evaluate mean fruit weight and total fruit yield per plant. In addition, the equatorial and Iongitudinal lengths of the whole fruits of a plant were measured and the average of these two values was defined as fruit size.

Six fruits were randomly chosen from the whole of harvested fruits in a plot, and these selected fruits were then cut into slices. Ten experts graded sensory characteristics of the fruits; with grading being numeric:5 (excellent), 4 (good), 3 (moderate), 2 (bad), and 1 (very bad) taking into account odor, taste, aroma, color, brightness, and hardness of fruit flesh (Fallik et al., 2001). The remaining flesh of the six selected fruits was blended and the resulting juice was filtered. Total soluble solids content in the juice was determined by a refractometer and expressed as a percentage. Acidity was determined by potentiometric titration to $\mathrm{pH} 8.1$ with $0.1 \mathrm{~N}$ $\mathrm{NaOH}$, using $50 \mathrm{~mL}$ of juice. Results were expressed as the percentage citric acid in juice (Mitcham et al., 1996). These analyses were done with three replications.

\section{Statistical analysis}

All data on growth, yield, and fruit quality were analyzed statistically by ANOVA as factorial randomized parcels design (Winer et al., 1991) using MINITAB statistical software. Means were found to be significantly different at the 0.05 level using Duncan's multiple range test. The ratings of sensory characteristics were not subjected to parametric testing.

\section{RESULTS}

\section{Irrigation and evapotranspiration}

The seasonal irrigation water amounts applied and evapotranspiration results for each variety are shown in Table 2. Irrigation water amounts between 171.4-551.9 mm were applied to the irrigated plots; in addition, those of $15.4 \mathrm{~mm}$ in 2005 and $34.7 \mathrm{~mm}$ in 2006 were applied to the non-irrigated treatment at plantation to ensure seedlings began to grow. The necessity of treatments, seasonal irrigation water amount increased when the duration of irrigation season was long and higher irrigation water amount resulted in higher seasonal evapotranspiration as expected.

\section{Growth components}

The statistically analyzed results of shoot number per plant, shoot length, and female flower number per plant are shown in Table 3.

\section{Shoot number}

The mean shoot number per plant varied between 4.6 and 5.6 for Yuva and between 3.9 and 5.0 for Cantaloupe. In general, smaller shoot 
Table 2. Results of seasonal irrigation water amount and evapotranspiration

Çizelge 2. Mevsimlik bitki su tüketimi ve uygulanan sulama suyu miktarları sonuçları

\begin{tabular}{|c|c|c|c|c|c|}
\hline Year & Treatment & $\begin{array}{l}\text { Irrigation } \\
\text { number }\end{array}$ & $\begin{array}{l}\text { Irrigation water } \\
\text { applied (mm) }\end{array}$ & $\begin{array}{c}\text { Effective } \\
\text { rainfall (mm) }\end{array}$ & $\begin{array}{l}\text { Evapotranspiration } \\
\text { (mm) }\end{array}$ \\
\hline \multirow{5}{*}{2005} & $\mathrm{I}_{0}$ & 1 & 15.4 & \multirow{5}{*}{84.5} & 195.0 \\
\hline & $I_{f}$ & 6 & 182.6 & & 362.2 \\
\hline & $\mathrm{I}_{\mathrm{fs}}$ & 9 & 291.4 & & 471.0 \\
\hline & $I_{r}$ & 12 & 388.3 & & 499.0 \\
\hline & $I_{h}$ & 14 & 460.5 & & 525.4 \\
\hline \multirow{5}{*}{2006} & $\mathrm{I}_{0}$ & 1 & 34.7 & \multirow{5}{*}{50.5} & 227.9 \\
\hline & $l_{f}$ & 5 & 171.4 & & 364.6 \\
\hline & $I_{\text {fs }}$ & 8 & 269.4 & & 426.6 \\
\hline & $\mathrm{I}_{\mathrm{r}}$ & 14 & 441.4 & & 587.1 \\
\hline & $I_{h}$ & 18 & 551.9 & & 604.7 \\
\hline
\end{tabular}

numbers were counted in Cantaloupe than those counted in Yuva in both experimental years Irrigation treatments (I) did not significantly affect shoot number of Yuva melon. However, the effect of years on shoot number was found to be significant. Larger shoot numbers were counted in 2005 (5.3) than those counted in 2006 (4.8).

The $Y x I$ interaction was significant for shoot number in Cantaloupe. No significant differences in shoot number occurred among irrigation treatments (I) in year 2005, while the largest number of shoots formed in the $I_{0}$ and $I_{f}$ treatments (5.0-4.9) following the $I_{f s}$ treatment (4.4) in year 2006. In this year, shoot number was the lowest in the treatments of $I_{r}$ and $I_{h}(3.9)$ in which irrigation water was applied until the beginning of ripening and harvesting, respectively.

\section{Shoot length}

The mean shoot length was found to be between $161.6 \mathrm{~cm}$ and $222.5 \mathrm{~cm}$ for Yuva and between $124.5 \mathrm{~cm}$ and $190.6 \mathrm{~cm}$ for Cantaloupe. Irrigation applications increased shoot length in both cultivars, and longer shoots were formed in Yuva than those formed in Cantaloupe.

Significant differences were observed for the mean shoot length between years $(Y)$ and between irrigation treatments (I) in Yuva. Longer shoots were formed in year $2005(202.3 \mathrm{~cm})$ than those observed for year $2006(184.9 \mathrm{~cm})$. The longest shoots were obtained with Ih treatment $(213.0 \mathrm{~cm})$ following the $I_{r}$ treatment $(195.6 \mathrm{~cm})$. Shoot length was shorter and statistically similar in treatments with $I_{0}, I_{f}$ and $I_{f s}(161.6-188.8 \mathrm{~cm})$.
Irrigation treatments (I) significantly affected the mean shoot length for Cantaloupe. The longest shoots formed with $I_{h}$ treatment $(188.3 \mathrm{~cm})$ following $I_{r}$ treatment $(159.4 \mathrm{~cm})$. In addition, shoots were the shortest $(128.4 \mathrm{~cm})$ with nonirrigated treatment $\left(\mathrm{I}_{0}\right)$.

Shoot growth was particularly more evident with irrigation application at least until the beginning of fruit ripening $\left(\mathrm{I}_{\mathrm{r}}\right)$ and continuing irrigation during the ripening stage $\left(I_{h}\right)$ furthered shoot development in both cultivars.

\section{Female flower number}

Years (Y) and irrigation treatments (I) did not significantly affect the mean female flower count per plant. However, larger female flowers formed in Yuva (8.8-13.5) than those in Cantaloupe (2.64.3).

\section{Yield components}

The results of the mean number of fruits per plant, fruit size, fruit weight, and fruit yield per plant are shown in Table 4 including statistical analysis. The YXl interaction for the whole yield components was found to be significant in both cultivars. 
Table 3. Results of growth components

Çizelge 3. . Vejetatif gelișme parametreleri sonuçları

\begin{tabular}{|c|c|c|c|c|c|c|c|c|c|c|}
\hline \multirow{3}{*}{$\begin{array}{l}\text { Irrigation } \\
\text { treatment }\end{array}$} & \multicolumn{5}{|c|}{ Yuva } & \multicolumn{5}{|c|}{ Cantaloupe } \\
\hline & \multicolumn{2}{|c|}{$\begin{array}{l}\text { (1) Shoot } \\
\text { number per } \\
\text { plant }\end{array}$} & \multicolumn{3}{|c|}{ (2) Shoot length $(\mathrm{cm})$} & \multicolumn{2}{|c|}{$\begin{array}{l}\text { (1) Shoot number per } \\
\text { plant }\end{array}$} & \multicolumn{3}{|c|}{ (2) Shoot length $(\mathrm{cm})$} \\
\hline & 2005 & 2006 & 2005 & 2006 & Average & 2005 & 2006 & 2005 & 2006 & Average \\
\hline $\mathrm{I}_{0}$ & 5.2 & 5.0 & 183.9 & 161.6 & $172.8 C^{2}$ & $4.0 \mathrm{~b} \mathrm{~A}^{\mathrm{y}}$ & 5.0 а A & 124.5 & 132.2 & $128.4 C^{2}$ \\
\hline$l_{f}$ & 5.3 & 5.1 & 194.0 & 188.8 & $191.4 \mathrm{BC}$ & $3.9 \mathrm{~b} \mathrm{~A}$ & 4.9 а $A$ & 132.0 & 160.6 & $146.3 \mathrm{BC}$ \\
\hline $\mathrm{I}_{\mathrm{fs}}$ & 5.6 & 4.7 & 192.3 & 171.2 & $181.8 \mathrm{C}$ & 4.4 а $\mathrm{A}$ & 4.4 а $A B$ & 151.6 & 132.0 & $141.8 \mathrm{BC}$ \\
\hline $\mathrm{I}_{\mathrm{r}}$ & 5.2 & 4.8 & 222.5 & 195.6 & $209.1 \mathrm{AB}$ & 4.6 а A & 3.9 a B & 166.9 & 151.9 & $159.4 \mathrm{~B}$ \\
\hline$I_{h}$ & 5.3 & 4.6 & 218.6 & 207.3 & $213.0 \mathrm{~A}$ & 4.5 a $A$ & 3.9 a B & 185.9 & 190.6 & $188.3 \mathrm{~A}$ \\
\hline \multirow[t]{3}{*}{ Average } & $5.3 a^{2}$ & $4.8 \mathrm{~b}$ & 202.3 a & $184.9 \mathrm{~b}$ & & & & & & \\
\hline & \multicolumn{2}{|c|}{$\begin{array}{l}\text { (3) Female } \\
\text { flower number } \\
\text { per plant }\end{array}$} & & & & \multicolumn{2}{|c|}{$\begin{array}{l}\text { (3) Female flower } \\
\text { number per plant }\end{array}$} & & & \\
\hline & 2005 & 2006 & & & & 2005 & 2006 & & & \\
\hline $\mathrm{l}_{0}$ & 12.1 & 8.8 & & & & 3.4 & 3.4 & & & \\
\hline$I_{f}$ & 13.2 & 10.6 & & & & 3.6 & 3.4 & & & \\
\hline $\mathrm{l}_{\mathrm{fs}}$ & 13.5 & 10.1 & & & & 3.6 & 3.5 & & & \\
\hline$I_{r}$ & 11.1 & 11.1 & & & & 2.6 & 2.8 & & & \\
\hline$I_{h}$ & 10.8 & 10.8 & & & & 4.3 & 3.4 & & & \\
\hline Source & & (1) & (2) & (3) & & (1) & (2) & (3) & & \\
\hline Year (Y) & & $* * * x$ & * & ns & & $* * * x$ & ns & ns & & \\
\hline $\begin{array}{l}\text { Irrigation } \\
\text { treatment (I) }\end{array}$ & & ns & ** & ns & & ns & $* * *$ & ns & & \\
\hline YxI & & ns & ns & ns & & $* *$ & ns & ns & & \\
\hline
\end{tabular}

${ }^{z}$ Small and capital letters indicate significantly differences among $Y$ and among I, respectively.

${ }^{\mathrm{y}}$ Bold small, and capital letters indicate significantly differences among $\mathrm{Y}$ in each I and among I in each $\mathrm{Y}$, respectively.

${ }^{x} \mathrm{~ns},{ }^{*},{ }^{* *},{ }^{* * *}$ : Non-significant or significant at $\mathrm{p} \leq 0.05,0.01,0.001$, respectively.

\section{Fruit number}

The mean fruit number per plant varied between 1.4 and 3.5 for Yuva and between 2.2 and 3.9 for Cantaloupe. For Yuva melon, more fruits developed on plants in the $\mathrm{I}_{\mathrm{f}}$ treatment in year 2005 (3.5) and in the treatments of $I_{f}$ and $I_{r}$ in year 2006 (2.4) than the other treatments. The lowest fruit number was counted in the non-irrigated treatment $\left(l_{0}\right)$ in both years. However, the lowest value was also obtained in the $\mathrm{I}_{\mathrm{h}}$ treatment in which irrigation water was applied until the beginning of harvest in year 2005.

The largest fruit number for Cantaloupe melon was counted in the treatments of $\mathrm{I}_{\mathrm{fs}}$ and $\mathrm{I}_{\mathrm{r}}$ in 2005 and in the $I_{h}$ treatment in 2006; in addition, the lowest values were obtained in the $\mathrm{I}_{0}$ treatment in 2005 and in the treatments of $\mathrm{I}_{0}$ and $\mathrm{I}_{\mathrm{fs}}$ in 2006. Irrigation applications significantly increased fruit number in both cultivars compared with nonirrigation in general. However, a consistent increase or decrease in fruit number could not be obtained by increasing the duration of irrigation season.

\section{Fruit size}

The mean variation in fruit size was between $14.0 \mathrm{~cm}$ and $16.2 \mathrm{~cm}$ for Yuva and $13.8 \mathrm{~cm}$ and $17.6 \mathrm{~cm}$ for Cantaloupe. Irrigation treatments (I) did not significantly affect fruit size in year 2005 (15.2$16.0 \mathrm{~cm}$ ) except in the case of the $I_{\mathrm{f}}$ treatment, in which smaller fruits were obtained for Yuva melon $(14.0 \mathrm{~cm})$. In contrast to the results of year 2005, the largest fruits were formed in the $\mathrm{I}_{\mathrm{f}}$ treatment $(16.2 \mathrm{~cm})$ in year 2006. For Cantaloupe, larger fruits were obtained in the treatments of $\mathrm{I}_{\mathrm{fs}}, \mathrm{I}_{\mathrm{r}}$, and $I_{h}$ in year $2005(15.8-16.6 \mathrm{~cm})$ and in the $I_{f}$ 
treatment in year $2006(17.6 \mathrm{~cm})$. In 2006, fruit size obtained in the treatments of $I_{f s}, I_{r}$, and $I_{h}$ was smaller, even relative to that obtained with nonirrigated treatment $\left(I_{0}\right)$.

Fruit weight. The mean fruit weight ranged from $1580 \mathrm{~g}$ to $2828 \mathrm{~g}$ for Yuva and from $1452 \mathrm{~g}$ to $2504 \mathrm{~g}$ for cantaloupe. Heavier fruits were harvested in the treatments of $I_{f s} I_{r}$, and $I_{h}$ (2006$2168 \mathrm{~g}$ ) in year 2005 , and in the $I_{h}$ treatment (2828 g) in year 2006, than those harvested in the other treatments for Yuva melon. For Cantaloupe, the heaviest fruits were obtained with the $\mathrm{I}_{\mathrm{r}}$ treatment $(2309 \mathrm{~g})$ in 2005 and with the treatments of $\mathrm{I}_{\mathrm{r}}$ and $I_{\mathrm{h}}$ (2317-2504 g) in 2006. Irrigation applications generally increased fruit weight, and statistically similar and heavier fruits were obtained in the treatments of $I_{r}$ and $I_{h}$ for both cultivars except in the $I_{r}$ treatment in 2005 for Yuva.

\section{Fruit yield}

The mean fruit yield per plant varied between $2474 \mathrm{~g}$ and $6206 \mathrm{~g}$ for Yuva melon and between $3601 \mathrm{~g}$ and $9766 \mathrm{~g}$ for Cantaloupe melon. The highest yields were obtained in the treatments of $\mathrm{I}_{\mathrm{fs}}$ and $I_{r}(6296 \mathrm{~g}$ and $6105 \mathrm{~g})$ in 2005 and in the treatments of $I_{r}$ and $I_{h}(6206 \mathrm{~g}$ and $6177 \mathrm{~g})$ in 2006 for Yuva. Although statistically similar yields were obtained in the treatments of $I_{r}$ and $I_{h}$ in 2006 the $I_{h}$ treatment reduced yield in 2005. For Cantaloupe, the highest yield was $7533 \mathrm{~g}$ in the $\mathrm{I}_{\mathrm{r}}$ treatment in year 2005 and $9766 \mathrm{~g}$ in the $\mathrm{I}_{\mathrm{h}}$ treatment in year 2006. Continuing irrigation during the ripening stage $\left(I_{h}\right)$ significantly increased yield in 2006 compared with irrigation applied until the beginning of fruit ripening $\left(\mathrm{I}_{\mathrm{r}}\right)$. However, this application significantly reduced yield in year 2005. The lowest yields were generally obtained in the non-irrigated treatment $\left(I_{0}\right)$, consequently, irrigation applications significantly increased yield for both cultivars.

\section{Fruit quality components}

The results of total soluble solids (TSS), titratable acidity (TA), and ratings of sensory characteristics (RSC) of fruit flesh are shown in Table 5 with statistical analysis for TSS and TA.

Table 4. Results of yield components

Çizelge 4. Verim parametreleri sonuçları

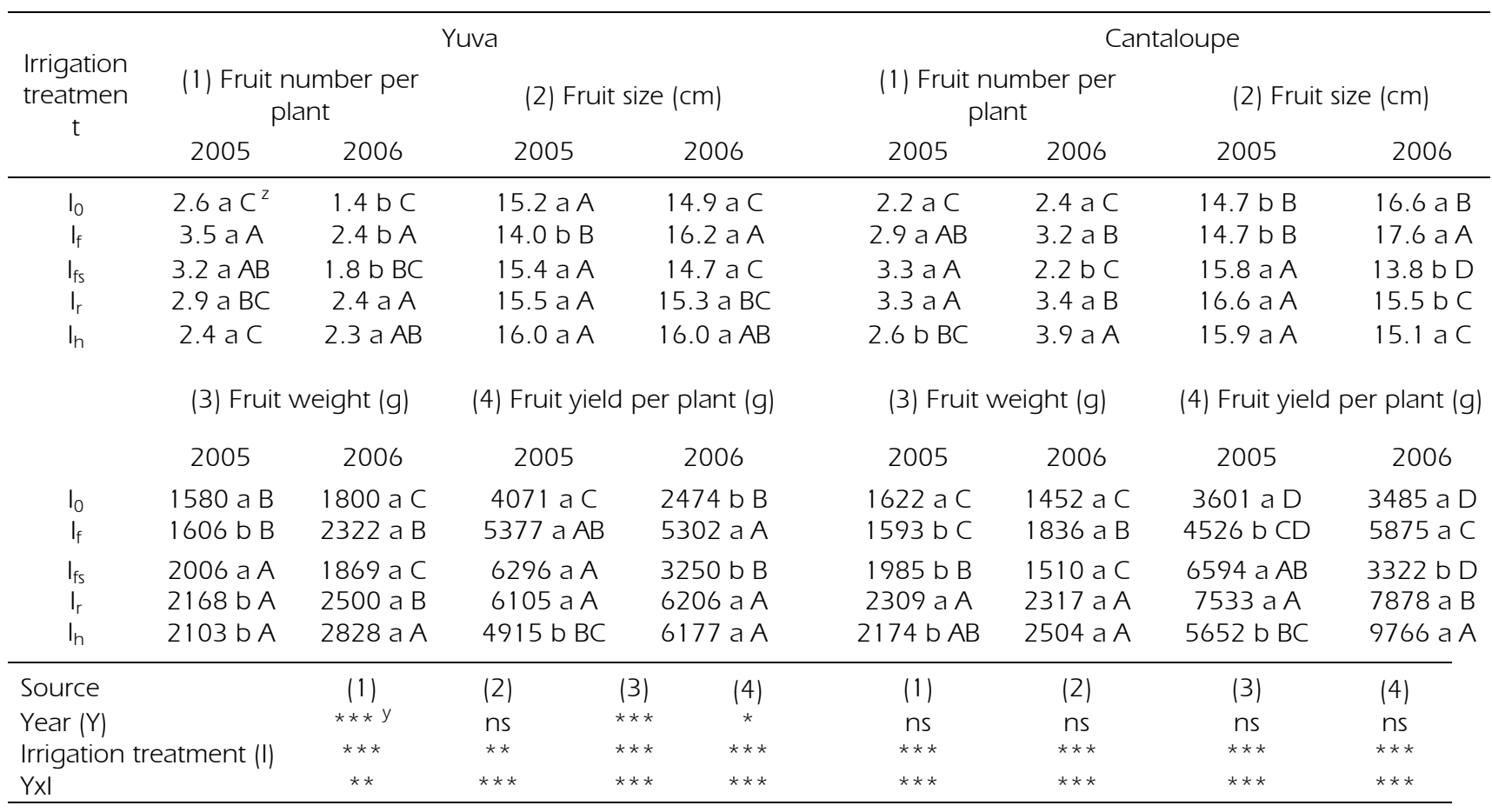

${ }^{2}$ Small and capital letters indicate significantly differences among $\mathrm{Y}$ in each I and among I in each $\mathrm{Y}$, respectively.

${ }^{y} \mathrm{~ns},{ }^{*}, * *, * *$ : Non-significant or significant at $\mathrm{p} \leq 0.05,0.01,0.001$, respectively. 


\section{Total soluble solids}

The mean total soluble solids of fruit flesh ranged from $8.4 \%$ to $10.1 \%$ for Yuva and from $8.6 \%$ to $11.3 \%$ for Cantaloupe. TSS was not significantly affected by years $(\mathrm{Y})$ and irrigation treatments (I) for Yuva while these factors significantly affected TSS of Cantaloupe.

For Cantaloupe, higher TSS was obtained in 2006 (10.0\%) than that obtained in 2005 (9.2\%). The highest TSS was measured in the non-irrigated treatment $\left(\mathrm{I}_{0}, 10.6 \%\right)$ following the treatments of $\mathrm{I}_{\mathrm{f}}$ (9.9\%) and $I_{h}$ (9.6\%). TSS was lower in the other irrigation treatments. Irrigation applications caused a reduction of TSS.

\section{Titratable acidity}

Titratable acidity (TA) varied between $0.08 \%$ and $0.17 \%$ for Yuva and between $0.03 \%$ and $0.09 \%$ for Cantaloupe. TA values of fruit flesh in Cantaloupe were significantly lower than those in Yuva. For Yuva melon, irrigation treatments (I) significantly affected
TA irrespective of years (Y). The highest and lowest TA values were found for $I_{0}(0.15 \%)$ and $I_{h}(0.09 \%)$ treatments, respectively. TA values were generally moderate in the other treatments. Irrigation applications reduced TA and this reduction was further evident in the $I_{h}$ treatment in which irrigation was continued during the ripening stage. For Cantaloupe melon, the Yxl interaction was found to be significant. The highest TA was obtained in the treatments of $\mathrm{I}_{0}$ and $\mathrm{I}_{\mathrm{fs}}$ in $2005(0.06 \%)$ and in the $\mathrm{I}_{\mathrm{h}}$ treatment in 2006 (0.09\%).

\section{Ratings of sensory characteristics}

The mean ratings of sensory characteristics varied between 2.9 and 4.5 for Yuva and between 3.1 and 4.6 for Cantaloupe. The highest RSC were obtained in the non-irrigated treatment $\left(I_{0}\right)$ for both cultivars in both years (4.3-4.6). The lowest ratings were registered in the $I_{\mathrm{fs}}$ treatment in Yuva in both years (2.9-3.1). In Cantaloupe, RSC were the lowest in the treatments of $I_{f}$ and $I_{h}$ in 2005 (3.1), and in the $I_{f s}$ treatment in 2006 (3.5).

Table 5. Results of fruit quality components

Çizelge 5. Meyve kalite parametreleri sonuçları

\begin{tabular}{|c|c|c|c|c|c|c|c|c|c|c|}
\hline \multirow{3}{*}{$\begin{array}{l}\text { Irrigation } \\
\text { treatment }\end{array}$} & \multicolumn{5}{|c|}{ Yuva } & \multicolumn{5}{|c|}{ Cantaloupe } \\
\hline & \multicolumn{2}{|c|}{$\begin{array}{l}\text { (1) Total } \\
\text { soluble } \\
\text { solids (\%) }\end{array}$} & \multicolumn{3}{|c|}{$\begin{array}{c}\text { (2) Titratable acidity } \\
\text { (\% citric) }\end{array}$} & \multicolumn{3}{|c|}{$\begin{array}{l}\text { (1) Total soluble } \\
\text { solids (\%) }\end{array}$} & \multicolumn{2}{|c|}{$\begin{array}{l}\text { (2) Titratable acidity } \\
\text { (\% citric) }\end{array}$} \\
\hline & 2005 & 2006 & 2005 & 2006 & Average & 2005 & 2006 & Average & 2005 & 2006 \\
\hline $\mathrm{I}_{0}$ & 9.1 & 9.7 & 0.12 & 0.17 & $0.15 A^{2}$ & 9.8 & 11.3 & $10.6 A^{2}$ & 0.06 а $A^{y}$ & $0.03 \mathrm{~b} \mathrm{~B}$ \\
\hline$I_{f}$ & 9.1 & 10.1 & 0.12 & 0.12 & $0.12 \mathrm{~B}$ & 9.1 & 10.6 & $9.9 \mathrm{AB}$ & 0.05 а $A B$ & 0.03 a B \\
\hline $\mathrm{l}_{\mathrm{fs}}$ & 8.9 & 9.6 & 0.11 & 0.12 & $0.12 \mathrm{~B}$ & 8.9 & 9.2 & $9.1 \mathrm{~B}$ & 0.06 а $A$ & 0.05 a $B$ \\
\hline$I_{r}$ & 8.5 & 9.3 & 0.12 & 0.11 & $0.12 \mathrm{~B}$ & 8.6 & 9.2 & $8.9 \mathrm{~B}$ & 0.03 а B & 0.03 a $B$ \\
\hline $\ln$ & 8.4 & 8.8 & 0.10 & 0.08 & $0.09 \mathrm{C}$ & 9.2 & 9.5 & $9.6 \mathrm{AB}$ & 0.03 b B & 0.09 а $A$ \\
\hline \multirow[t]{3}{*}{ Average } & & & & & & $9.2 \mathrm{~b}^{2}$ & $10.0 \mathrm{a}$ & & & \\
\hline & \multicolumn{3}{|c|}{$\begin{array}{l}\text { (3) Ratings of sensory } \\
\text { characteristics }\end{array}$} & & & \multicolumn{3}{|c|}{$\begin{array}{l}\text { (3) Ratings of sensory } \\
\text { characteristics }\end{array}$} & & \\
\hline & 2005 & & 2006 & & & 200 & & 2006 & & \\
\hline $\mathrm{I}_{0}$ & 4.5 & & 4.3 & & & 4.6 & & 4.5 & & \\
\hline$I_{f}$ & 4.3 & & 4.1 & & & 3.1 & & 3.9 & & \\
\hline $\mathrm{l}_{\mathrm{fs}}$ & 3.1 & & 2.9 & & & 3.6 & & 3.5 & & \\
\hline$I_{r}$ & 3.7 & & 3.7 & & & 4.4 & & 3.7 & & \\
\hline $\mathrm{ln}_{\mathrm{h}}$ & 3.6 & & 3.0 & & & 3.1 & & 4.4 & & \\
\hline \multicolumn{2}{|l|}{ Source } & \multicolumn{2}{|r|}{ (1) } & (2) & & & (1) & (2) & & \\
\hline \multirow{2}{*}{\multicolumn{2}{|c|}{$\begin{array}{l}\text { Year (Y) } \\
\text { Irrigation treatment (I) }\end{array}$}} & \multicolumn{2}{|c|}{$\mathrm{ns}^{\mathrm{x}}$} & ns & & & * & ns & & \\
\hline & & \multicolumn{2}{|c|}{ ns } & $* * *$ & & & * & ** & & \\
\hline YXI & & & ns & ns & & & ns & $* * *$ & & \\
\hline
\end{tabular}

${ }^{z}$ Small and capital letters indicate significantly differences among $Y$ and among I, respectively.

${ }^{y}$ Bold small, and capital letters indicate significantly differences among $Y$ in each I and among I in each $Y$, respectively.

${ }^{x} \mathrm{~ns},{ }^{*},{ }^{* *},{ }^{* * *}$ : Non-significant or significant at $\mathrm{p} \leq 0.05,0.01,0.001$, respectively. 


\section{DISCUSSION}

\section{Growth}

As shown in Table 3, the higher values related to growth components such as shoot number, shoot length, and female flower count were obtained in Yuva than those in Cantaloupe. This result may be attributed to cultivar characteristics. On the other hand, although female flower count did not depend on irrigation treatments, a positive relation was observed between vegetative growth (considering shoot length and the number of shoots per plant) and the duration of irrigation season (consequently amount of seasonal irrigation water applied). Hence continuing irrigation during ripening stage $\left(I_{h}\right.$ treatment) furthered shoot growth. These findings are similar the results obtained by Pew and Gardner (1983) and Ribas et al. (2000) who found that vegetative growth was higher under full irrigation instead of limited irrigation.

\section{Yield}

Compared with the non-irrigated treatment, irrigation applications generally increased the number of fruits per plant in both cultivars (Table 4). However, a regular increment in fruit number could not be found with increasing the duration of irrigation season. This does not confirm the suggestion by Hernandez et al., (1995) that more fruits form on melon plants under full irrigation rather than limited irrigation. Our findings that higher irrigation water amounts result in larger fruits or a consistent increase in fruit size. However, continuing irrigation during the ripening stage did not significantly vary fruit size in both cultivars in general., This result agrees with the findings of Meiri et al. (1995) and Hartz (1997), in that irrigation during ripening stage does not affect fruit size, and with the findings of Sousa et al. (1999) in that the effect of irrigation frequency on fruit size was not significant. On the other hand, Matheis and Fellman (1999) have reported that irrigation close to harvest could result in an increase in fruit volume.

This study shows that irrigation applications increase fruit weight compared with no irrigation, and this increase in fruit weight was also found when irrigation was employed until the beginning of fruit ripening or harvest. Pew and Gardner (1983) revealed that milder limited irrigation did not affect fruit weight of melon, however, excessive soil moisture deficit in the root zone resulted in small fruits. In this study, irrigation applications significantly increased fruit yield in both cultivars compared with no application of irrigation. The highest fruit yields were obtained for irrigation from transplantation to the beginning of ripening stage in Yuva melon. For Cantaloupe melon, continuing irrigation during ripening stage caused yield reductions in 2005 and yield increments in 2006. Thus, it can be concluded that continuing irrigation during ripening stage should not be necessary for Cantaloupe.

Yield results obtained in this study were similar to findings reported by others irrigation results in increased melon yield (DeTar et al., 1983); both full and mildly limited irrigation does not significantly affect melon yield (Pew and Gardner 1983; Hernandez et al., 1995; Alizadeh et al. 1999); considerably limited irrigation should increase melon yield instead of the use of full irrigation (Gil et al., 2000; Lei et al., 2003 Sensoy et al, 2007; Tekiner et al., 2010); and limited irrigation during the stages of flowering and fruit development causes yield reduction and soil water deficit during ripening period but does not result in significant differences in fruit yield (Faberio et al., 2002). This report is in contrast with the findings of Ribas et al. (2001), in which they found that limited irrigation reduces fruit yield of melon.

\section{Fruit quality}

Irrigation resulted in the reduction of total soluble solids, which are primarily the sugar content of fruit flesh. It also decreased the ratings of sensory characteristics in both cultivars in general. However, it could be concluded that continuing irrigation during fruit development and ripening stages could result in considerably higher soluble solid contents. This finding is consistent with results of previous investigations in which it was found that soil water deficit during the ripening stage causes increases or otherwise does not affect fruit quality, particularly of soluble solids, and that excessive water deficit during the whole production period causes an increase in the soluble solids content (Warriner and Henderson, 1989; Shishido et al., 1992; Hartz, 1997; Gil et al., 2000). In contrast, Matheis and Fellman (1999) reported that irrigation close to harvest should reduce soluble solids content and the sensory characteristics ratings. 


\section{CONCLUSIONS}

With respect to considerably high yield and the savings achieved by witholding irrigation water throughout the ripening stage, irrigation applied from transplantation to the beginning of fruit ripening is recommended as the most suitable irrigation program (Ir treatment) for drip-irrigated Yuva and Cantaloupe melons grown under semiarid climatic conditions based on the findings of this study. In this irrigation program, total soluble solids contents and sensory characteristics ratings are likely to reach levels of acceptability with regard to expectations of considerably high fruit quality.

\section{Acknowledgements}

We express our gratitude to The Scientific and Technological Research Council of Turkey (TUBITAK) for supporting our research (Project Nr. $104 \mathrm{O}$ 495). The results presented in this paper were partially taken from the PhD theses titled 'Effect Of Different Irrigations Programs On Fruit Yields And Quality Of Melon Under Drip Irrigation' completed at the Institute for PhD studies in University of Ankara, Faculty of Agriculture, Department of Farm Structures and Irrigation.

\section{REFERENCES}

Anonymous, 2003. Agricultural Structure 2001. State Institute of Statistics, Prime Ministry, Republic of Turkey, Ankara.

Alizadeh K A, Baghani J M, . Haghnia G M (1999). Effect of deficit irrigation by drip and furrow systems on the yield and quality of melon at Mashad, Iran. In: 17th ICID International Congress on Irrigation and Drainage, pp: 263-269, 13-17 September 1999, Vol. 1C, Granada-Spain.

Amor F M del, Carvajal M, Martinez V, Cerda A, Amor F M del, Marcelis LF M (1998). Response of muskmelon plants (Cucumis melo L.) to irrigation with saline water. In: Second International Symposium on Models for Plant Growth, Environmental Control and Farm Management in Protected Cultivation, 25-28 August 1997, Wageningen- Netherlands, Acta Horticulturae, 456: 263-268.

Barros, V. da S, Costa R N T, Aguiar J V de, Barros da S V. de Aguiar JV (2002). Irrigation and nitrogen fertilization effect on melon crop yield. IRRIGA, 7 (2): 98-105.

BATEM

http://mww.batem.gov.tr/urunler/sebzelerimiz/kavun/kavun. htm. (Access date: 16.04.2010)

Bhella HS (1985). Muskmelon growth, yield, and nutrition as influenced by planting method and trickle irrigation. J. Am. Soc. Hortic. Sci. 26: 793-796.

Bogle C R, Hartz T K (1986). Comparison of drip and furrow irrigation for muskmelon production. Hortscience, 21 : 242-244
Cabello M J, Castellanos M T, Romojaro F, MartinezMadrid C, Ribas F (2009). Yield and quality of melon grown under different irrigation and nitrogen rates. Agricultural Water Management, 96 (5), 866-874.

Coelho E F, de Sousa V F, Rodrigues B H N, de Souza V $A B$, Andrade $C$, de Sousa $\vee F$, de Sousa $\vee A$ B, de Andrade $C$ (1999). Melon yield under different irrigation intervals and placement of drip lines in cohesive sandy soils. Revista Brasileira de Engenharia Agricola e Ambiental, 3 (3): 309-315.

Dasgan H Y, Kırda C, Baytorun N, Abak K, Büyükalaca S (1999). Water and nitrogen relationships in fertigated greenhouse grown melon (Cucumis melo L.). In: Proceedings of the First International Symposium on Cucurbits, Adana, Turkey, 20-23 May 1997, Acta Horticulturae, 492: 233-236.

De Tar WR, Kibler D F, Grenoble D W, Daniels R, Cole R H, Tukey L D, Hampson S H, Geller S C (1983). Trickle irrigation vs. no irrigation of five horticultural crops in Pennsylvania. Transactions of the ASAE, 26: 82-86.

Dogan E, Kırnak H, Berekatoglu K, Bilgel L, Surucu A (2008). Water Stress Imposed on Muskmelon (Cucumis melo L.) with Subsurface and Surface Drip Irrigation Systems under Semi-Arid Climatic Conditions. Irrigation science, 26:131-138.

Faberio C, Santa Olalla F M, Juan J A (2002). Production of muskmelon (Cucumis melo L.) under controlled deficit irrigation in a semi-arid climate. Agricultural Water Management, 54 (2): 93-105.

Fallik E, Tuvia S A, Horev B, Copel A, Rodov V, Aharoni Y, Ulrich D, Shultz H (2001). Characterization of Galia melon aroma by GC and mass spectrometric sensor measurements after prolonged storage. Postharvest Biology and Technology, 22: 85-91.

Flocker W J, Lingle J C, Davis R M, Miller R J (1965). Influence of irrigation and nitrogen fertilization on yield, quality and size of cantaloupes. Proc. Am. Soc. Hortic. Sci., 86: 424-432.

Gil J A, Montano N, Khan L (2000). Effect of four irrigation strategies on the yield and its components in two cultivars of melon (Cucumis melo L.). RABSU, 1 (2): 48-52.

Günay A (1992). Vegetable Production (Özel Sebze Yetiștiriciliği), Cilt:V., Çağ Matbaası, Ankara. (In Turkish)

Hartz T K (1997). Effects of drip irrigation scheduling on muskmelons yield and quality. Scientia Horticulturae, 69 (12): $117-122$.

Hernandez F B T, Bedum J A A, Suzuki M A, Buzetti S (1995). Effect of irrigation levels on yield of muskmelons in the Ilha Solteira Region, Sao Paulo. Cultura Agronomica, $4(1): 1$ 10

Jensen M E, Burman R D, Allen R G (Ed.) (1989). Evapotranspiration and irrigation water requirements, ASCE, Manuals and Reports on Engineering Practice 70, New York.

Kușvuran Ș, Ellialtıoğlu Ș, Yașar F, Abak K (2007). Effects of salt stress on ion accumulation and activity of some antioxidant enzymes in melon (Cucumis melo L.). Journal of Food, Agric. and Environ., 5: 351-354. 
Lei T W, Xiao J, Wang J P, Liu Z Z, Li G Y, Zhang J G, Mao $\mathrm{J} H$ (2003). Experimental investigation into effects of drip irrigation with saline ground water on water use efficiency and quality of honeydew melons in Hetao Region Inner Mongolia. Transactions of the CSAE, 19 (2): 80-84.

Leskovar D I, Ward J C, Sprague R W, Meiri A (2001). Yield, quality and water use efficiency of muskmelon affected by irrigation and transplanting versus direct seeding. Hortscience 36 (2): 286-291.

Lester G E, Obeker N F, Coons J (1994). Preharvest furrow and drip irrigation schedule effects on postharvest muskmelon quality. Postharvest Biology and Technology, 4 (1-2): 57-63.

Mattheis J P, Fellman J K (1999). Preharvest factors influencing flower of fresh fruit and vegetables. Postharvest Biology and Technology, 15: 227-232.

Medlinger S, Fossen M (1993). Flowering, vegetative growth, yield, and fruit quality in musk melons under saline conditions. J. Am. Soc. Hort. Sci., 118 (6): 868-872.

Meiri A, Lauter D J, Sharabani N (1995). Shoot growth and fruit development of muskmelon under saline and non saline soil water deficit, Irrigation Science, 16 (1): 15-21.

Merriam J L, Keller J (1978). Farm Irrigation System Evaluation: A Guide for Management. Utah State Univ., Logan, USA.

Mitcham B, Cantwell M, Kader A (1996). Methods determining quality of fresh commodities. Perishables Handling Newsletter Issue No: 85, pp:1-5.

Papazafiriou Z G (1980). A compact procedure for trickle irrigation system design. ICID Bull., 29: 28-45.

Pew W D, Gardner B R (1983). Effects of irrigation practices on vine growth, yield and quality of muskmelons, J. Am. Soc. Hort. Sci., 108: 134-137.

Ribas F, Cabello M J, Moreno M M, Moreno A, Lopez Bellido $L$ (2001). Effect of irrigation and potassium application in melon (Cucumis melo L.) production, I: Yield. Investigacion Agraria, Produccion Y Proteccion Vegetales, 16 (2): 283-297.

Sakaldas M, Öztakat C, Kaynaș K(2009). Hasat sonrası 1Methylcyclopropane uygulamalarının farklı sıcaklık derecelerinde depolanan kavunlarda (Cucumis melo L. cv. Dellteks F1) meyve kalitesi üzerine olan etkileri. Süleyman Demirel Üniversitesi Ziraat Fakltesi Dergisi, 4 (1): 1-9.

Sarı N, Abak K, Dașgan H Y (2000). Güneydoğu Anadolu bölgesinde kavun yetiștiriciliği. TÜBITAK, TARP Yayınları, 20s.

Shishido Y, Yahashi T, Seyama N, Imada S (1992). Effects of leaf position and water management on translocation and distribution of $14 \mathrm{C}$ assimilates in fruiting muskmelons. J. the JSHC, 60 (4): 897-903.

Shmueli M, Goldberg D (1971). Sprinkler, furrow and trickle irrigation of muskmelon in an arid zone. Hortscience, 7 : 241-243.

Sousa V F De, Coelho E F, Sousa V A B de, Sousa V F de (1999). Irrigation frequency in melons cultivated in sandy soil. Pesquisa Agropecuaria Brasileira, 34 (4): 659-664.

Șalk A, Arın L, Deveci M, Bolat S (2008). Özel Sebzecilik.
Onur Grafik Matbaacılık ve Reklam Hizmetleri. İstanbul. ISBN: 978-9944-0786-0-3.

Șengül N (2009). Damla yöntemiyle sulanan kavunda farklı sulama programlarının meyve verimi ve kalitesi üzerine etkileri. Ankara Üniversitesi, Fen Bil. Enst. Doktora Tezi. $111 \mathrm{~s}$.

Șensoy S, Ertek A, Gedik I, Küçükyumuk C (2007). Irrigation frequency and amount affect yield and quality of field-grown melon (Cucumis melo L.), Agricultural Water Management, 88: 1-3, pp: 269-274.

Tekiner M, Öztokat C, Taș I (2010). Effects of irrigation programs on growth, yield, and fruit quality of drip-irrigated melon in Dardanelles (Canakkale) Troia Region, 2nd International Symposium on Sustainable Development, June 8-9 2010, Sarajevo. Issd 2010 Science Book, pp: 144-149.

Warriner S A, Henderson R D (1989). Rockmelon irrigation management for market quality. In: Research and Development Conference on Vegetables, The Market Producer, 11-15 July, 1988, Richmond, Australia, pp: 239-242.

Winer B J, Brown D R, Michels K M (1991). Statistical principles in experimental design. McGrow Hill, Boston, USA.

Yıldırım O (2005). Design of irrigation systems. (Sulama sistemlerinin tasarımı) (2. Baskı). Ankara Üniv. Ziraat Fak. Yayınları 1542, Ankara. (In Turkish).

Yıldırım O, Halloran N, Cavusoğlu S, Sengul, N (2009). Effects of different irrigation programs on the growth, yield, and fruit quality of drip-irrigated melon. Turk. J. Agric. For., 33: 243-255. 